\title{
Detection, Distribution, and Genetic Variability of European mountain ash ringspot-associated virus
}

\author{
A. K. Kallinen, I. L. Lindberg, A. K. Tugume, and J. P. T. Valkonen
}

Department of Applied Biology, P.O. Box 27, FIN-00014 University of Helsinki, Finland.

Accepted for publication 11 October 2008.

\begin{abstract}
Kallinen, A. K., Lindberg, I. L., Tugume, A. K., and Valkonen, J. P. T. 2009. Detection, distribution, and genetic variability of European mountain ash ringspot-associated virus. Phytopathology 99:344-352.

European mountain ash ringspot-associated virus (EMARAV) was recently characterized from mountain ash (rowan) (Sorbus aucuparia) in Germany. The virus belongs tentatively to family Bunyaviridae but is not closely related to any classified virus. How commonly EMARAV occurs in ringspot disease (EMARSD) affected mountain ash trees was not reported and was investigated here. Virus-specific detection tools such as reverse transcription-polymerase chain reaction and dot blot hybridization using digoxigenin-labeled RNA probes were developed to test 73 mountain ash trees including 16 trees with no virus-like symptoms from 16 districts in Finland and Viipuri, Russia. All trees were infected with

cause latent infections in mountain ash. Symptom expression and the variable relative concentrations of viral RNA detected in leaves showed no correlation. Infectious EMARAV was detected also in dormant branches of trees in winter. Subsequently, genetic variability, geographical differentiation, and evolutionary selection pressures were investigated by analyzing RNA3 sequences from 17 isolates. The putative nucleocapsid (NP) gene sequence (944 nucleotides) showed little variability (identities 97 to 99\%) and was under strong purifying selection. Amino acid substitutions were detected in two positions at the $\mathrm{N}$ terminus and one position at the $\mathrm{C}$ terminus of NP in four isolates. The $3^{\prime}$ untranslated region (442 nucleotides) was more variable (identities 94 to $99 \%$ ). Six isolates from a single sampling site exhibited as wide a genetic variability as isolates from sites that were hundreds of kilometers apart and no spatial differentiation of populations of EMARAV was observed.
\end{abstract} EMARAV. Hence, EMARAV is associated with EMARSD and can also
Viruses in the family Bunyaviridae have multipartite genomes consisting of negative-sense and ambisense RNA molecules encapsidated in enveloped, large particles 80 to $110 \mathrm{~nm}$ in diameter (8). Most viruses in Bunyaviridae infect vertebrates and/or invertebrates but tospoviruses (genus Tospovirus) infect plants and invertebrates (thrips in the genera Frankliniella and Thrips). Besides these genomic and host range properties unusual for most plant viruses, one of the tospoviruses (Tomato spotted wilt virus, TSWV) has the broadest host range among the known plant viruses. It is therefore perhaps unexpected that only eight confirmed and six tentative species of plant viruses are known to belong to this family (8). Recently, a new tentative member of family Bunyaviridae was described from mountain ash, or rowan (Sorbus aucuparia L.; Rosaceae: Maloideae), in Germany (16). Interestingly, this virus infects a tree and seems to be associated with one of the most commonly observed virus-like diseases in the wild in northern Europe $(11,12,20)$.

Mountain ash is a self-incompatible and insect-pollinated tree whose seeds are dispersed mainly by birds (21). It is native to Europe and common in the wild especially in areas with a cool climate and relatively abundant rainfall. In Finland, mountain ash is very common and shows continuous geographical distribution, whereas in central and southern parts of Europe it occurs mainly on mountainous areas where the climate is more suitable (22). Mountain ash is also grown as an ornamental tree owing to its modest size, the decorative compound inflorescences each consisting of ca. 250 flowers, and the attractive orange-red edible berries. It has been introduced to North America where it may behave as an invasive species (21).

Corresponding author: J. P. T. Valkonen; E-mail address: jari.valkonen@ helsinki.fi

doi:10.1094/PHYTO-99-4-0344

(c) 2009 The American Phytopathological Society
In Europe, mountain ash is often found to display ringspot symptoms in leaves. The typical ringspot disease of European mountain ash (hereafter referred to as EMARSD) was reported for the first time by Jamalainen (11) in Finland. He illustrated the symptoms with a photograph and described them as yellowish gray-green angular lesions visible on the upper side of the leaf. Leaflets could be fully covered by the symptoms and in some trees leaflets contained necrotic lesions. More extensive necrosis was observed as death of the edges and tips of leaflets (11). Kegler (12) observed similar symptoms in mountain ash trees in the eastern parts of Germany and concluded the symptoms to be identical to the symptoms reported by Jamalainen. The symptoms appeared early in leaves that were just a few days old. Kegler reported successful transmission of the disease agent to healthy mountain ash plants by chip budding and documented the resultant EMARSD symptoms with two photographs. Symptoms appeared the year after chip budding. Kegler (12) also commented the early studies of Baur (3) who investigated an infectious and graft-transmissible variegation of leaf color in an ornamental variety ' $S$. aucuparia fol. luteo-variegatis' in Germany. In Kegler's opinion, the description of symptoms by Baur did not match with EMARSD and were attributable to another disease agent, which still remains to be identified.

For a long time, a virus was suspected to cause EMARSD but etiology of the disease remained unresolved. Cooper (6) reported EMARSD in the United Kingdom and illustrated the symptoms in a photograph. He mentioned lack of success in transmitting any disease agent in foliar sap of EMARSD-affected trees to herbaceous indicator hosts. Sweet and Campbell (25) found that mountain ash can be infected experimentally with Apple chlorotic leaf spot virus (ACLSV), the type member of the genus Trichovirus (8). ACLSV and Apple mosaic virus (ApMV, genus Ilarvirus) (8) were found to be common in mountain ash trees displaying EMARSD in the Czech Republic (20). However, as 
ACLSV (14) and ApMV with some difficulty (9) can be transmitted mechanically in leaf sap of their woody hosts to herbaceous indicator plants, Cooper's studies (6) suggested that these viruses were not the probable causal agents of EMARSD. Indeed, there are no reports on mechanical transmission of the EMARSD agent.

A breakthrough was achieved recently by Benthack et al. (4) who isolated double-stranded RNA of 7.0, 2.3, 1.5, and $1.3 \mathrm{~kb}$ from leaves and bark of EMARSD-affected trees in Germany. Subsequently, four negative-sense RNA molecules of 7,040, 2,335, 1,560, and 1,348 nucleotides (RNA1 to RNA4, respectively) were characterized, of which RNA1 was predicted to encode an RNA-dependent RNA polymerase related to viruses in the family Bunyaviridae (16). RNA2 contained a gene for a putative glycoprotein related to the genus Phlebovirus (Bunyaviridae), whereas the putative nucleocapsid protein (NP) encoded by RNA3 and the protein encoded by RNA4 showed no similarity to any classified viruses. Hence, the virus could not be assigned to any existing genus (16). The findings were consistent with previous studies that had revealed tospovirus-like enveloped particles of 80 to $100 \mathrm{~nm}$ in EMARSD-affected leaves (7). The name European mountain ash ringspot-associated virus (EMARAV) was proposed (16) but it remained for future studies to find out how widely and commonly EMARAV occurs in EMARSD-affected trees. To find it out, virus-specific detection methods would be needed.

The aim of this study was investigate the occurrence of EMARAV in EMARSD-affected and symptomless mountain ash trees in different parts of Finland. For this purpose, sensitive virus-specific molecular detection methods were developed for diagnosis of EMARAV using the NP-encoding RNA3 as the target. Because only a single isolate of EMARAV had been characterized previously at the molecular level (16), the aim of this study was to gain information about the population structure of EMARAV by analysis of the RNA3 sequences for genetic variability and selection pressure.

\section{MATERIALS AND METHODS}

Plant material. Leaves of mountain ash trees were collected from 16 districts in Finland and from Russia in the town of Viipuri (part of Finland until 1944) (Fig. 1). Samples were taken in June and early July 2007 and stored at $-20^{\circ} \mathrm{C}$. The numbers of samples from different districts were as follows: Hamina (5), Helsinki (12), Joroinen (1), Jyväskylä (4), Jämsä (2), Kuopio (1), Leppävirta (1), Mikkeli (1), Pirkkala (4), Ristiina (14), Ruukki (2), Siilinjärvi (1), Sipoo (2), Toijala (2), Turku (5), Vihti (14), and Viipuri (2). Of the 73 trees sampled, 56 trees displayed symptoms of EMARSD (Fig. 2).

Apical parts $(30 \mathrm{~cm})$ of branches were cut from a mountain ash tree in Viikki at the University of Helsinki on 21 March and 20 April 2008, before the dormancy of buds was broken. At both times, seven branches were sampled. The twigs were placed in a vase with water and grown in a plant growth room at a constant temperature $\left(22^{\circ} \mathrm{C}\right)$ under illumination with white fluorescent lamps (photoperiod $16 \mathrm{~h}$, light intensity $100 \mu \mathrm{E} \mathrm{s}^{-1} \mathrm{~m}^{-2}$ ). Fourteen days later, leaves were collected at an early growth stage and tested for EMARAV. On 13 May, the first symptoms of ringspot disease were visible in the young leaves of the tree and samples were taken from them for virus detection.

Isolation of total RNA and synthesis of cDNA. Leaf samples were frozen in liquid nitrogen and ground in a mortar with a pestle. Total RNA was extracted essentially as described (16) with slight modifications, including preparation of silica gel according Boom et al. (5). Ground frozen plant tissue $(100 \mathrm{mg})$ was homogenized in $1 \mathrm{ml}$ of extraction buffer consisting of $4 \mathrm{M}$ guanidine hydrochloride, $0.2 \mathrm{M}$ sodium acetate $(\mathrm{pH} 5.2), 1 \mathrm{M}$ potassium acetate, $0.025 \mathrm{mM}$ ethylenediaminetetra-acetic acid (EDTA; Fluka, Buchs, Switzerland), and 2.5\% polyvinyl pyrrolidone (PVP-
40; Sigma, St. Louis, MO). Tubes were inverted occasionally during incubation at $70^{\circ} \mathrm{C}$ for $10 \mathrm{~min}$ after which they were placed on ice for $5 \mathrm{~min}$. The suspension was spun at $12,000 \times g$ at $4^{\circ} \mathrm{C}$ for $10 \mathrm{~min}$. The supernatant was divided into two new tubes and $300 \mu \mathrm{l}$ of sodium iodide solution $(6 \mathrm{M}$ sodium iodide and $0.15 \mathrm{M}$ sodium sulfite), $150 \mu \mathrm{l}$ ethanol, and $25 \mu \mathrm{l}$ of silica suspension ( $1 \mathrm{~g} \mathrm{ml}^{-1}, \mathrm{pH} 2.0$ ) were added. The solution was incubated at room temperature with gentle shaking for $10 \mathrm{~min}$ and spun at $12,000 \times g$ for $10 \mathrm{~min}$. Supernatant was removed and silica particles were washed twice with a buffer $(10 \mathrm{mM}$ Tris- $\mathrm{HCl}$ [pH 7.5], $0.5 \mathrm{mM}$ EDTA, $50 \mathrm{mM} \mathrm{NaCl}$, and $50 \%$ ethanol) and once with ethanol. The silica particles were resuspended in $200 \mu \mathrm{l}$ of deionized $\mathrm{H}_{2} \mathrm{O}$, incubated at $70^{\circ} \mathrm{C}$ for $5 \mathrm{~min}$, and spun at $12,000 \times g\left(4^{\circ} \mathrm{C}, 5 \mathrm{~min}\right)$. The two aliquots of same sample were combined. Total RNA was extracted with phenol/chloroform/ isoamylalcohol (25:24:1), precipitated by ethanol, and resuspended in RNase-free $\mathrm{H}_{2} \mathrm{O}$. RNA was quantified with a spectrophotometer (Gene Quant 1300, GE Healthcare, Chalfont St. Giles, Buckinghamshire, UK).

cDNA was synthesized in a volume of $20.5 \mu \mathrm{l}$ using $1 \mu \mathrm{g}$ of total RNA, random hexamer primers, and Moloney murine leukemia virus (MMLV) reverse transcriptase (Promega, Madison, WI) according to the manufacturer's instructions.

Detection of EMARAV by polymerase chain reaction (PCR). PCR primers were designed according to the sequence of the gene for the putative NP of EMARAV (GenBank accession no. DQ831831). Two pairs of primers were designed to be used

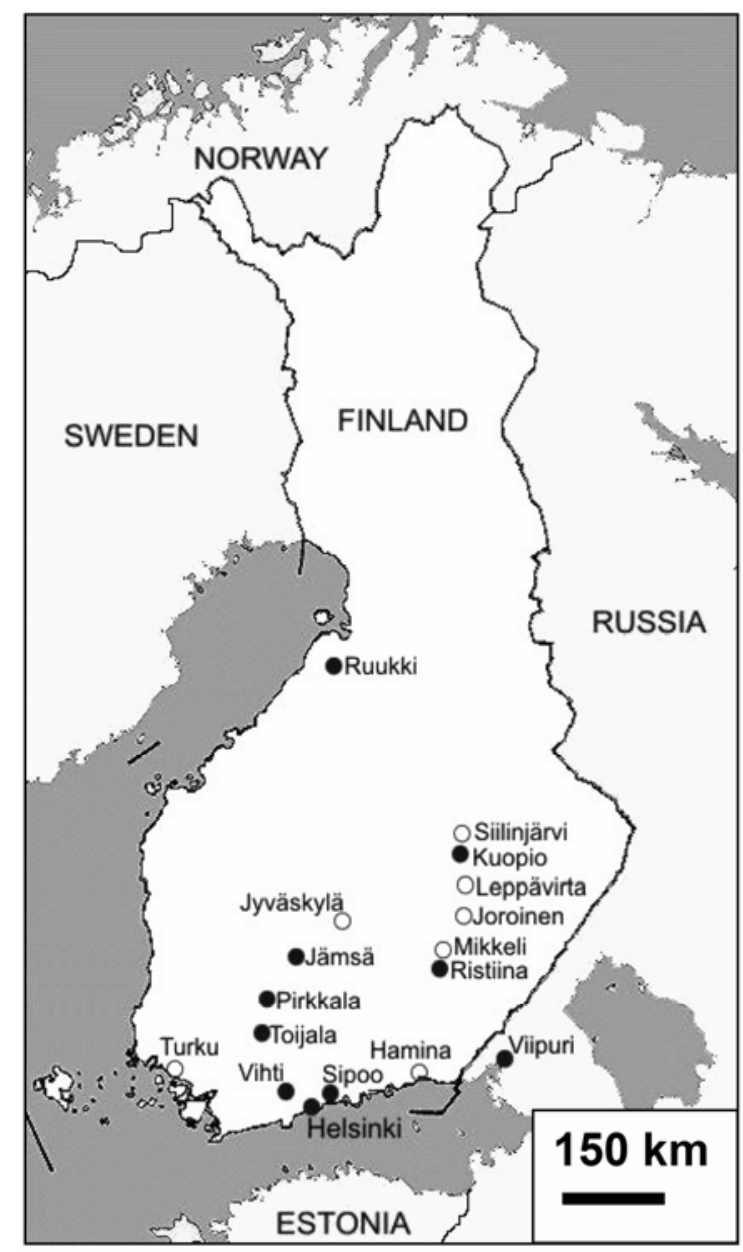

Fig. 1. Sixteen districts in Finland and one district in Russia from which leaves of mountain ash were collected and tested for European mountain ash ringspot-associated virus (EMARAV). Seventeen isolates of EMARAV were characterized for the RNA3 sequence and the districts from which these isolates were sampled are marked with black dots. 
for detection of EMARAV: NC30F and NC1190R, and NC525F and NC908R (Table 1; Fig. 3). The PCR reaction $(20 \mu \mathrm{l})$ consisted of $4 \mu \mathrm{l}$ of $5 \times$ Phusion high-fidelity (HF) buffer, $0.4 \mu \mathrm{l}$ of $10 \mathrm{mM}$ dNTPs, $0.5 \mu \mathrm{l}$ of $20 \mu \mathrm{M}$ primers, $0.2 \mu \mathrm{l}(0.4 \mathrm{U})$ Phusion HF DNA polymerase (Finnzymes, Espoo, Finland), and $2.5 \mu \mathrm{l}$ of cDNA. The cycling parameters were $95^{\circ} \mathrm{C}$ for $1 \mathrm{~min}$, followed by 40 cycles of $95^{\circ} \mathrm{C}$ for $10 \mathrm{~s}, 59^{\circ} \mathrm{C}$ for $30 \mathrm{~s}$, and $72^{\circ} \mathrm{C}$ for $30 \mathrm{~s}$, and final extension at $72^{\circ} \mathrm{C}$ for $5 \mathrm{~min}$. Amplification products were analyzed by electrophoresis in $1 \%$ agarose gel containing ethidium bromide $\left(0.1 \mu \mathrm{g} \mathrm{ml}^{-1}\right)$ and visualized under UV light.

Digoxigenin-labeled RNA probe and dot blot hybridization. The 383-nucleotides long PCR product amplified from the NP gene with primers NC525F and NC908R designed in this study (Table 1) was ligated to the pGEM-T Vector (Promega, Madison, WI) and cloned in Escherichia coli (strain DH5 $\alpha$ ). The plasmid was purified with GenElute Plasmid Miniprep Kit (SigmaAldrich, St. Louis, MO). An RNA probe was synthesized and labeled with digoxigenin by in vitro transcription with T7 RNA polymerase according to the manufacturer's instructions (Promega).

For detection with the digoxigenin-labeled RNA probe, $1 \mu \mathrm{g}$ of total RNA $\left(0.25 \mu \mu^{-1}\right)$ extracted from leaves was denatured at $95^{\circ} \mathrm{C}$ for $10 \mathrm{~min}$ and cooled quickly on ice. The sample $(4 \mu \mathrm{l})$ was transferred onto a positively charged nylon membrane (Roche, Basel, Switzerland) and fixed under UV light. Hybridization with the probe and detection with anti-digoxigenin antibodies were carried out as described (The Dig Application Manual for Filter Hybridization, Roche).

Sequencing and sequence analysis. The putative NP gene sequences of EMARAV isolates were determined from three overlapping clones obtained by PCR using the primer pairs NC30F
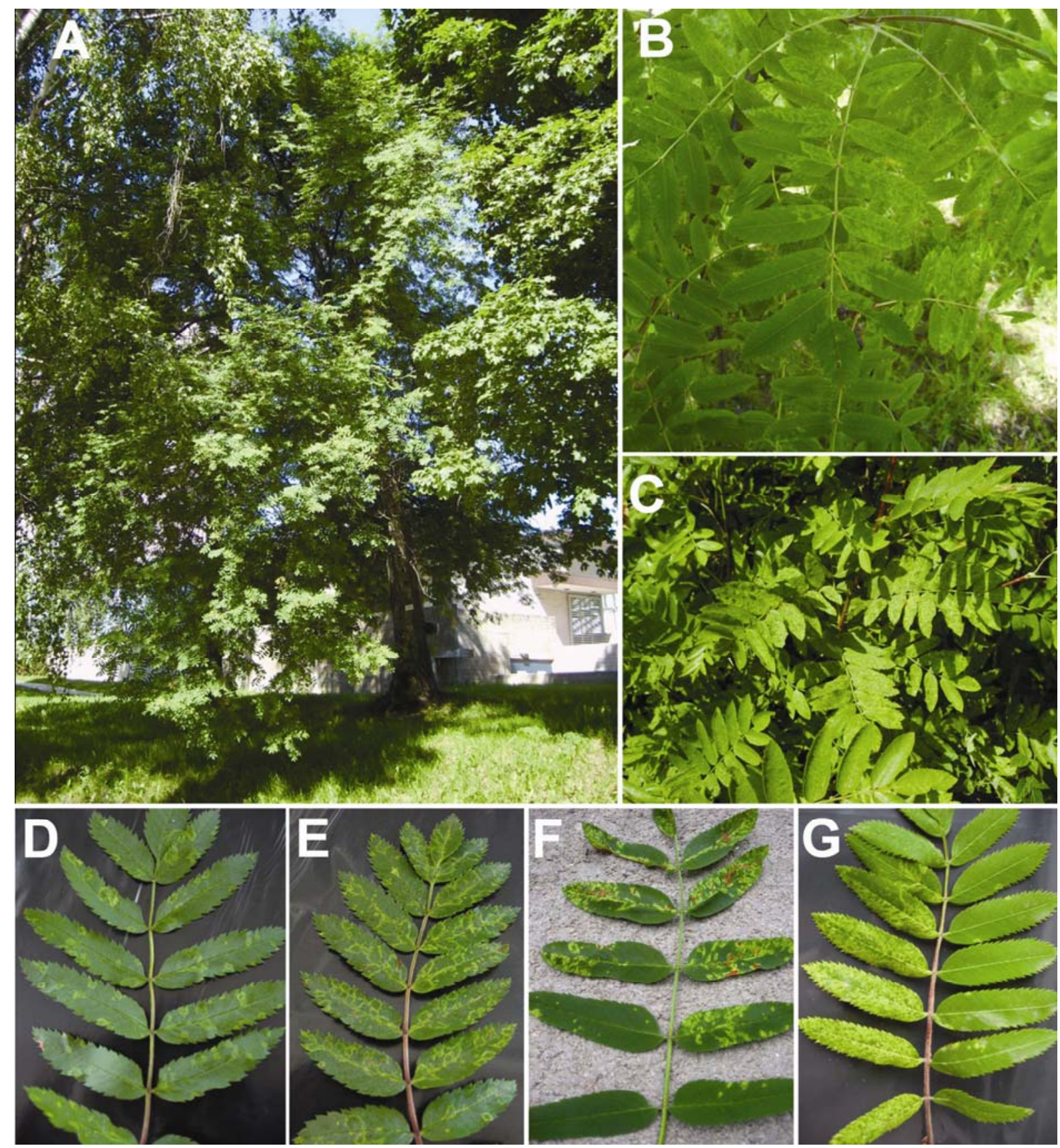

Fig. 2. Symptoms observed in mountain ash leaves infected with European mountain ash ringspot-associated virus. B, Close-up of a branch of the mountain ash tree in A. Isolate Hel41 was characterized from this tree. Four types of symptoms (leaves D to G) were found in this tree in the lowest branches that were always in shade. D, A few ringspot lesions; $\mathbf{E}$, many ringspot lesions and a few necrotic lesions; $\mathbf{D}$, angular chlorotic lesions, ringspot-like lesions and necrotic areas in leaves; G, extensive chlorosis and only few discernible ringspots, symptoms almost exclusively expressed on one half of the leaf. C, Symptoms observed in a bush of young 2- to 3-year-old mountain ash plants growing from seeds or roots of an older plant (Ristiina). 
and NC908R, NC525F and NC1190R, and NC963F and NC1557R (Table 1). PCR products were subjected to direct sequencing with Applied Biosystems Dye Terminator (version 3.1) sequencing kit (Applied Biosystems, Foster City, CA) and a capillary sequence analyzer at the Haartman Institute, Sequencing Core Facility, University of Helsinki, using the PCR primers. For two fragments, primers NC255R and NC1285F were designed to sequence the $5^{\prime}$ end and $3^{\prime}$ end which did not overlap with any other fragment (Table 1).

TABLE 1. Primers used for amplification and sequencing of RNA3 of European mountain ash ringspot-associated virus

\begin{tabular}{llc}
\hline Name & \multicolumn{1}{c}{ Sequence } & Position $^{\mathrm{a}}$ \\
\hline NC30F & 5'-TCAACAACTCTTTTAAGCACATCA-3' $^{\prime}$ & $1507-1530$ \\
NC255R & 5'TCTCTATTTCCCAATTATGCTTCA-3' $^{\prime}$ & $1305-1328$ \\
NC525F & 5'-GAGCCAAGAATGACTGAGCA-3' $^{\prime}$ & $1016-1035$ \\
NC908R & 5'-CTGCCAAAGTGAACCCAAAT-3' & $652-671$ \\
NC963F & 5'-CATCTGTGGTGTGCCTGAGT-3' & 578-587 \\
NC1190R & 5'-TCGACTATGCTGGTCTTGGA-3' & $370-389$ \\
NC1285F & 5'-TGCAATGTTACCCCTCATGT-3' & $256-275$ \\
NC1557R & 5'-TAGTGAACTCCCATAATTTTGCT-3' & $3-25$ \\
\hline
\end{tabular}

a Positions according to the genomic negative-sense RNA3 (sequence accession DQ831831) (16).
Sequences were edited using the Vector NTI advance 10 program (Invitrogen, Carlsbad, CA). Primer sequences were removed and sequence alignments were made with Clustal W (27). Phylogenetic analysis was carried out using the neighbor-joining algorithm (24) and the Kimura 2-parameter nucleotide substitution model (13) in MEGA4 (26).

Analysis of selection pressure. The ratio of nonsynonymous $\left(d_{\mathrm{N}}\right)$ to synonymous $\left(d_{\mathrm{S}}\right)$ nucleotide substitution rate $\left(\omega=d_{\mathrm{N}} / d_{\mathrm{S}}\right)$ provides a sensitive measure of selective constraints at the protein level. Values of $\omega<1, \omega=1$, and $\omega>1$ indicate purifying (or negative) selection, neutral evolution, and diversifying (or positive) selection, respectively, according to which the direction and intensity of selection pressure on a functional protein can be predicted (10,18). The maximum likelihood (ML) approach was applied on the putative EMARAV NP gene using site models of codon substitution implemented in the CODEML program of PAML4 (31). Under the basic assumption of a codon as a unit of evolutionary change (10), site models treat $\omega$ for any codon in a protein-encoding nucleotide sequence as a random variable from a statistical distribution. The probability of observing data was computed as the log likelihood which was the sum of probabilities over all codons in the sequence. Selection pressure was examined by assessing the value $\omega$ and comparing the log likeli-

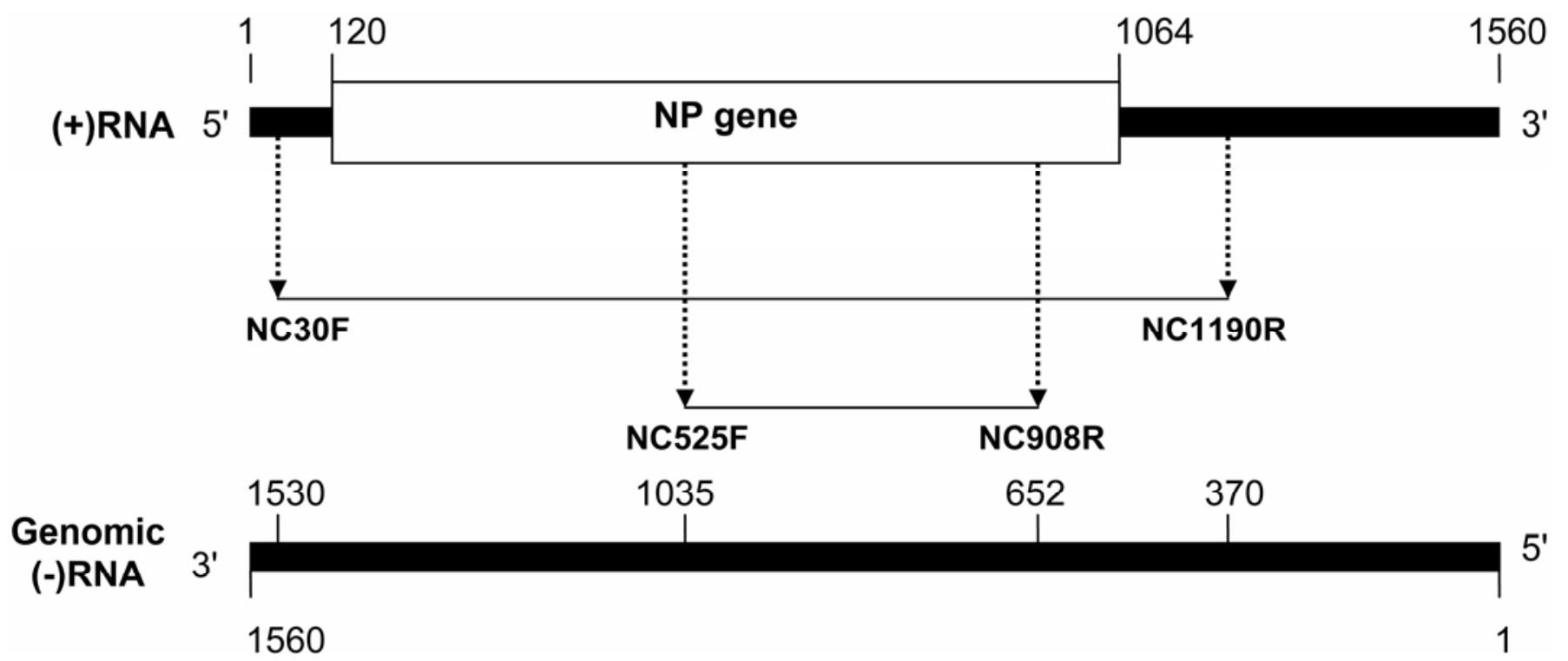

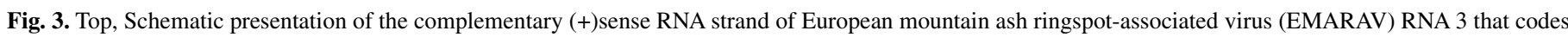

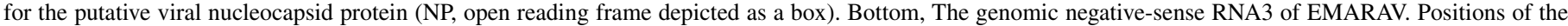

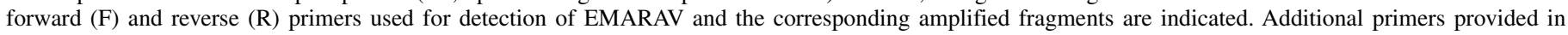
Table 1. Numbering is with reference to the sequence DQ831831.

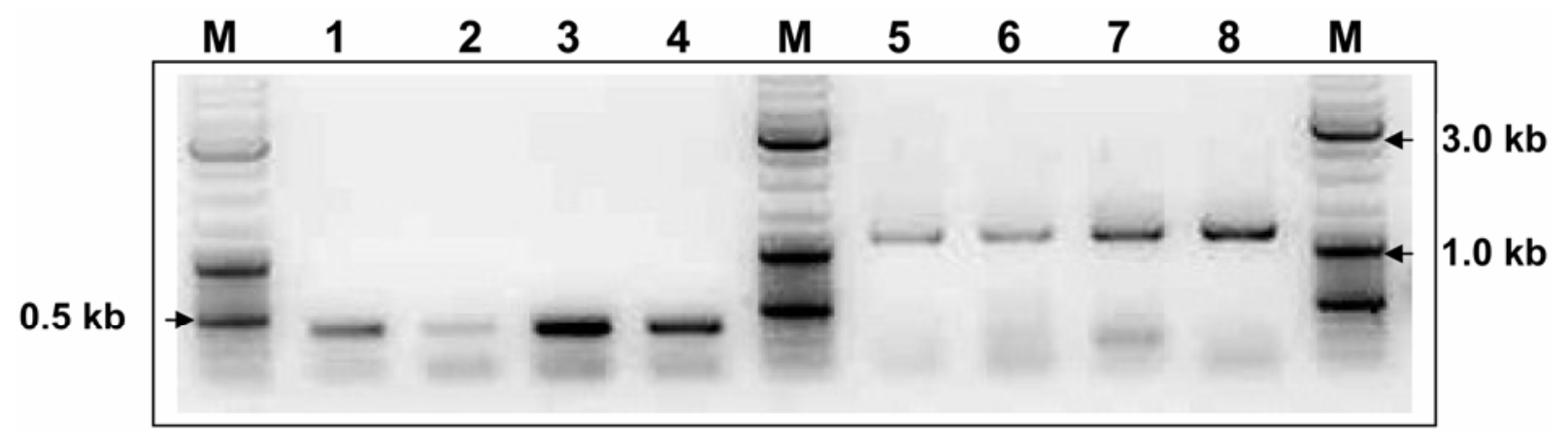

Fig. 4. Detection of European mountain ash ringspot-associated virus (EMARAV) with two nucleocapsid protein gene-specific primer pairs NC525F and NC908R (samples 1 to 4) and NC30F and NC1190R (samples 5 to 8) resulting in amplification products of 0.38 and $1.16 \mathrm{~kb}$, respectively. 1, Jam9; 2, Toi11; 3, Ris61; 4, Sip62; 5, Jam9; 6, Hel37; 7, Ris61; and 8. Sip62. Sequences of Jam9, Ris61, Sip62, and Toi11 were determined (Table 1). M, DNA size marker (Gene Ruler DNA Ladder Mix, Fermentas, St. Leon-Rot, Germany). The strongest bands in M correspond to markers of 3.0, 1.0, and 0.5 kb. 
hoods of nested models (M0 versus M3, M1a versus M2a, and M7 versus M8) as described (30).

\section{RESULTS}

Virus-like symptoms in mountain ash. The virus-like symptoms observed in mountain ash trees varied (Fig. 2). The most characteristic ringspot symptoms (Fig. 2D and E) were observed in the leaves of trees that looked healthy from a distance (Fig. 2A). Only closer examination revealed the ringspots on leaves (Fig. 2B and C). Sometimes a few necrotic lesions were also observed among the ringspots (Fig. 2E). Some leaves displayed irregular chlorotic and necrotic lesions and only few ringspots were observed (Fig. 2F). The trees in which this type of symptom was predominant could be recognized as diseased from a distance of tens of meters. Some leaves displayed extensive chlorosis of leaflets with only few if any ringspots and necrotic lesions (Fig. 2G). All these types of symptoms could be observed in the same tree (Fig. 2), while it was also found that some trees displayed only one type of symptoms (usually those shown in Fig. 2E). Regardless of the predominant type of symptoms, it was often observed that not all leaves of the tree or branch, or not all leaflets of a leaf expressed symptoms. The symptoms could be confined to leaflets of only one side of the leaf.

Detection of EMARAV in mountain ash leaves. A total of 73 mountain ash trees were tested for EMARAV. They were sampled in 16 districts up to $500 \mathrm{~km}$ apart from each other in Finland and in Viipuri, Russia (Fig. 1). Detection of EMARAV with RT-PCR was carried out with two pairs of primers (Fig. 3) that amplified products of 383 and 1,160 nucleotides, respectively, from RNA3 (Fig. 4). Amplification products of the expected sizes were detected in ca. $50 \%$ of the samples when the products were analyzed by agarose gel electrophoresis and stained with ethidium bromide. Subsequently, the shorter PCR fragment of 383 nucleotides was sequenced from a few samples, found to be nearly-identical to the NP gene of the previously characterized isolate of EMARAV (16), and used for making an RNA probe labeled with digoxigenin. The total RNA extracted from the leaves was transferred to a membrane and tested by dot blot hybridization using the probe. The majority of samples generated readily detectable signals, whereas the signals in some samples were very faint (Fig. 5). Finally, the PCR products were transferred to a membrane and analyzed by dot blot hybridization using the digoxigenin-labeled probe. All samples were found to be positive when the total RNA had been DNase-treated prior to cDNA synthesis and PCR, which excluded the possibility that probes hybridized to plant DNA (data not shown). Taken together, EMARAV was detected in all samples, including leaves showing all the aforementioned types of symptoms (Fig. 2) and also leaves from 16 mountain ash trees that displayed no discernible viruslike symptoms.

A total of 14 apical parts $(30 \mathrm{~cm})$ of branches were cut from the same dormant mountain ash tree in March and April during the winter. The leaves that emerged on the cuttings in a growth room

TABLE 2. RNA3 sequences of isolates of European mountain ash ringspotassociated virus determined in this study

\begin{tabular}{lll}
\hline Isolate & \multicolumn{1}{c}{ Origin } & Accession number \\
\hline He141 & Helsinki & EU885280 \\
Jam9 & Jämsä & EU885278 \\
Kuo12 & Kuopio & EU885281 \\
Pir43 & Pirkkala & EU885282 \\
Ris50 & Ristiina & EU885283 \\
Ris51 & Ristiina & EU885284 \\
Ris52 & Ristiina & EU885285 \\
Ris54 & Ristiina & EU885286 \\
Ris56 & Ristiina & EU885287 \\
Ris60 & Ristiina & EU885288 \\
Ris61 & Ristiina & EU885289 \\
Ruu45 & Ruukki & EU885290 \\
Sip62 & Sipoo & EU885292 \\
Toi11 & Toijala & EU885293 \\
Vih2 & Vihti & EU885279 \\
Vih7 & Vihti & EU885277 \\
Vii19 & Viipuri, Russia & EU885291 \\
- & Hamburg, Germany & DQ831831 \\
\hline
\end{tabular}

${ }^{a}$ Determined by Mielke and Muehlbach (16).

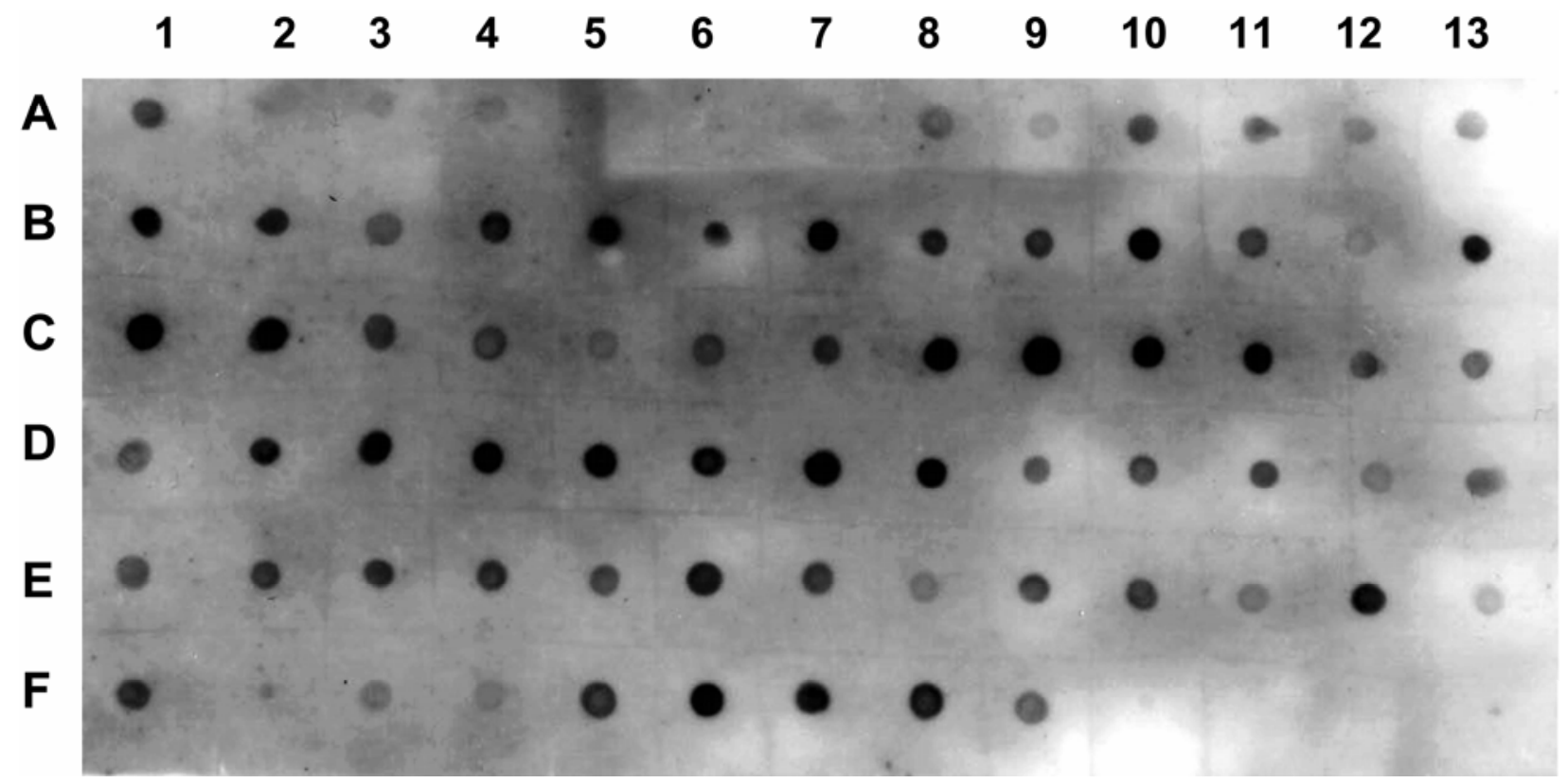

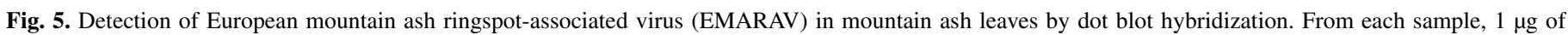

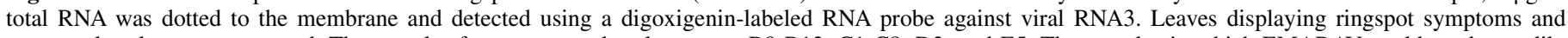

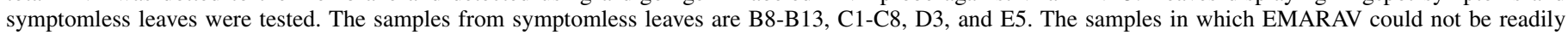

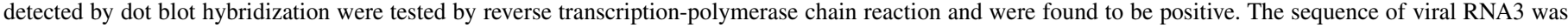

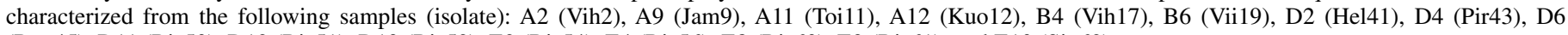
(Ruu45), D11 (Ris50), D12 (Ris51), D13 (Ris52), E2 (Ris54), E4 (Ris56), E8 (Ris60), E9 (Ris61), and E10 (Sip62). 
showed no symptoms. However, all were EMARAV-positive as tested by RT-PCR (data not shown). The leaves started developing on the tree 2 weeks after the second sampling and ringspots appeared on leaves that were 1 week old. The leaves were viruspositive as tested by RT-PCR (data not shown).

Sequence diversity and phylogenetic clustering of EMARAV isolates. Almost the whole sequence of RNA3 was determined in 17 isolates of EMARAV (Table 2). To avoid errors introduced by the DNA polymerase during PCR, the fragments subjected to sequencing were amplified using a DNA polymerase (Phusion) that shows a 25 -fold higher fidelity than the Taq DNA polymerase (2). The analyzed region (1,481 nucleotides out of the 1,560 nucleotides of RNA3) included a part (94 nucleotides) of the 5' untranslated region (5'UTR), the NP gene (944 nucleotides), and most of the $3^{\prime}$ UTR (442 nucleotides).

The NP gene showed some genetic variability which, however, resulted in only three amino acid substitutions among the isolates compared (Table 3). At amino acid position 45, the previously characterized isolate from Germany (DQ831831) contained a serine residue instead of glycine that was found in all isolates from Finland and the isolate characterized from Viipuri, Russia. Isolates Ris52 and Ris56 contained isoleucine instead of valine at position 55, and isolate Ris60 contained alanine instead of valine at position 328 in contrast to all other isolates (Table 3). These three isolates were collected from the same district at a very short distance from each other (Fig. 6). The overall NP nucleotide and amino acid sequence identities among the EMARAV isolates were 97 to $99 \%$ and 99 to $100 \%$, respectively (Table 4).

The 94 nucleotides determined from 5'UTR were identical in all isolates, with only a few exceptions. Isolate Kuo12 contained guanine instead of adenine at position 23 and thymine instead of cytosine at positions 43 and 78 compared with other isolates. Isolate Ris54 contained cytosine instead of thymine at position 82 (data not shown).

The 3'UTR was the most variable part of RNA3 (Table 4). The lowest identity (94\%) was found between isolates Ris50 and Ris61. The 3'UTR of isolate Ris61 was only $97 \%$ identical to Ris60 although these isolates were obtained from trees just $100 \mathrm{~m}$

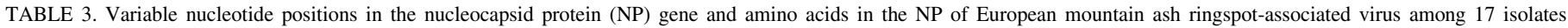
determined in this study and an isolate (DQ831831) determined in a previous study (16) ${ }^{\mathrm{a}}$

\begin{tabular}{|c|c|c|c|c|c|c|c|c|c|c|c|c|c|c|c|c|c|c|c|c|c|c|c|c|c|c|c|c|c|c|c|c|c|c|c|}
\hline $\begin{array}{l}\text { Nucleotide } \\
\text { position }\end{array}$ & $\stackrel{\infty}{=}$ & $\stackrel{\text { లి }}{-}$ & $\stackrel{\vec{m}}{2}$ & $\underset{0}{ }$ & $\stackrel{\Delta}{\Delta}$ & $\underset{d}{J}$ & ڤે & $\stackrel{\Delta}{\Delta}$ & $\stackrel{\hat{\Delta}}{\Delta}$ & $\stackrel{\curvearrowright}{\curvearrowright}$ & હે & సి & त & $\stackrel{\infty}{\sim}$ & 品 & ț & ন্ & $\frac{n}{z}$ & $\ddot{m}$ & 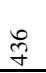 & $\hat{\sigma}$ & $\stackrel{m}{q}$ & $\stackrel{\infty}{\circ}$ & $\underset{n}{\infty}$ & 号 & in & $\underset{i n}{*}$ & $\underset{\infty}{\infty}$ & 命 & $\stackrel{\infty}{0}$ & $\frac{0}{6}$ & $\frac{\Delta}{6}$ & to & $\widetilde{V}$ & 응 \\
\hline Consensus & G & G & G & G & G & $\mathrm{C}$ & $\mathrm{T}$ & $\mathrm{C}$ & $\mathrm{C}$ & A & $\mathrm{T}$ & $\mathrm{T}$ & A & A & $\mathrm{C}$ & A & $\mathrm{C}$ & A & $\mathrm{T}$ & A & $\mathrm{T}$ & $\mathrm{T}$ & $\mathrm{T}$ & $\mathrm{C}$ & $\mathrm{C}$ & $\mathrm{C}$ & A & $\mathrm{T}$ & $\mathrm{T}$ & $\mathrm{C}$ & $\mathrm{C}$ & $\mathrm{C}$ & $\mathrm{T}$ & $\mathrm{C}$ & G \\
\hline Vih7 & . & . & . & . & . & . & . & . & . & . & . & . & . & . & . & . & . & G & . & . & . & . & . & . & . & . & . & . & . & . & . & . & . & . & . \\
\hline Ris50 & . & . & . & . & . & . & . & . & . & . & $\mathrm{C}$ & . & . & . & $\cdot$ & . & . & G & . & . & . & $\cdot$ & . & . & $\mathrm{T}$ & . & . & . & . & . & . & . & . & . & . \\
\hline Toi11 & . & . & . & . & . & . & . & . & . & . & . & . & . & . & $\mathrm{T}$ & . & . & G & . & . & . & $\mathrm{C}$ & . & . & . & $\mathrm{T}$ & . & . & . & . & . & . & . & . & . \\
\hline Ruu45 & . & . & . & . & . & . & . & . & . & . & . & . & . & . & . & . & . & G & . & G & $\mathrm{C}$ & $\cdot$ & . & . & . & . & . & . & . & . & . & $\mathrm{T}$ & . & . & . \\
\hline Sip62 & . & . & . & . & . & . & . & . & . & . & . & . & . & . & . & G & . & $\cdot$ & . & $\cdot$ & . & . & . & . & . & . & . & . & . & . & . & . & . & $\mathrm{C}$ & . \\
\hline DQ831831 & . & . & A & . & . & $\mathrm{T}$ & . & $\mathrm{T}$ & . & . & . & . & . & G & . & $\cdot$ & . & . & . & G & . & . & . & . & . & . & . & . & . & . & . & . & . & . & . \\
\hline Ris51 & . & . & . & . & . & . & . & . & . & . & . & . & . & . & . & . & $\mathrm{T}$ & . & . & . & . & . & . & . & . & . & . & . & . & . & $\mathrm{T}$ & . & . & . & . \\
\hline Ris54 & . & . & . & . & . & . & . & . & . & G & . & . & . & . & . & . & . & . & . & . & . & . & . & . & . & . & . & . & . & . & . & . & . & . & . \\
\hline Vii19 & . & . & $\cdot$ & $\cdot$ & $\cdot$ & $\cdot$ & . & . & . & $\cdot$ & . & . & . & . & . & . & . & . & . & . & . & . & $\mathrm{C}$ & . & . & . & . & . & . & . & . & . & . & . & . \\
\hline Pir43 & . & . & . & . & . & . & . & . & . & . & . & $\mathrm{C}$ & . & . & . & . & . & . & . & . & . & . & . & . & . & . & . & . & . & . & . & . & . & . & . \\
\hline Vih2 & . & . & . & . & . & . & . & . & . & . & . & . & . & . & . & . & . & . & . & . & . & . & . & . & . & . & . & . & . & . & . & . & . & . & . \\
\hline Hel41 & . & . & . & . & . & . & . & . & . & . & . & . & . & . & . & . & . & . & . & . & . & . & . & . & . & . & . & . & . & . & . & . & . & . & . \\
\hline Ris52 & . & . & . & A & . & . & $\mathrm{C}$ & . & A & . & . & . & . & . & . & . & . & . & $\mathrm{C}$ & . & . & . & . & . & . & . & . & . & . & . & . & . & . & . & . \\
\hline Ris56 & . & . & . & A & . & . & $\mathrm{C}$ & . & A & . & . & . & . & . & . & . & . & . & $\mathrm{C}$ & . & . & . & . & . & . & . & . & . & . & . & . & . & . & . & . \\
\hline Jam9 & . & A & . & $\cdot$ & . & . & $\cdot$ & . & $\cdot$ & . & . & . & . & . & . & . & . & . & $\cdot$ & . & . & . & . & . & . & . & . & . & . & . & . & . & . & . & . \\
\hline Ris60 & . & A & . & . & A & . & . & . & . & . & . & . & . & . & . & . & . & . & . & . & . & . & . & . & $\mathrm{T}$ & . & . & $\mathrm{C}$ & $\mathrm{C}$ & . & A & $\mathrm{T}$ & $\mathrm{C}$ & . & A \\
\hline Kuo12 & $\cdot$ & A & . & . & A & . & . & . & . & . & . & . & G & . & $\cdot$ & . & . & . & . & . & $\mathrm{C}$ & . & . & $\mathrm{T}$ & . & . & G & $\cdot$ & $\cdot$ & $\cdot$ & A & $\mathrm{T}$ & $\mathrm{C}$ & . & A \\
\hline Ris61 & A & A & . & . & A & . & . & . & . & . & . & . & . & . & $\mathrm{T}$ & . & . & . & . & . & . & . & . & $\mathrm{T}$ & . & . & $\mathrm{G}$ & . & . & $\mathrm{T}$ & $\mathrm{A}$ & $\mathrm{T}$ & $\mathrm{C}$ & . & A \\
\hline Amino acid & $\mathrm{S}$ & $\mathrm{G}$ & $\mathrm{G}$ & $\mathrm{V}$ & $\mathrm{T}$ & $\mathrm{N}$ & $\mathrm{R}$ & I & $S$ & $\mathrm{~N}$ & $\mathrm{~L}$ & $\mathrm{~L}$ & $\mathrm{~A}$ & $\mathrm{D}$ & $\mathrm{D}$ & $\mathrm{N}$ & $\mathrm{R}$ & $\mathrm{Q}$ & $\mathrm{L}$ & $\mathrm{R}$ & $S$ & $\mathrm{~T}$ & $\mathrm{~V}$ & $\mathrm{M}$ & I & $\mathrm{R}$ & $\mathrm{M}$ & $\mathrm{D}$ & $E$ & $\mathrm{~L}$ & $\mathrm{G}$ & $\mathrm{L}$ & $\mathrm{I}$ & $\mathrm{N}$ & $\mathrm{I}$ \\
\hline & . & . & $\mathrm{S}$ & I & . & . & . & . & . & $\cdot$ & . & . & . & $\cdot$ & $\cdot$ & . & . & . & . & . & . & . & . & $\cdot$ & . & . & $\cdot$ & $\cdot$ & . & . & $\cdot$ & $\cdot$ & . & $\cdot$ & . \\
\hline $\begin{array}{l}\text { Amino acid } \\
\text { position }\end{array}$ & 우 & 寸 & $\dddot{f}$ & $n$ & $\mathfrak{N}$ & $\bar{\infty}$ & $\infty$ & ส่ & ๙ & 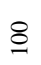 & 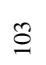 & $\hat{\varrho}$ & $\stackrel{\infty}{\ominus}$ & $\stackrel{\varrho}{=}$ & $\stackrel{0}{=}$ & I & 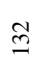 & ले & $\stackrel{\cong}{ \pm}$ & I & $\underline{n}$ & 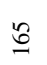 & 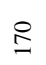 & $\stackrel{\infty}{\infty}$ & $\underset{\infty}{+}$ & $\stackrel{\infty}{\infty}$ & & $\Xi$ & 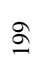 & $\hat{\tilde{d}}$ & ঙ্ণ & 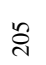 & $\frac{0}{\pi}$ & $\stackrel{\infty}{\sim}$ & $\underset{\sim}{\mathbb{N}}$ \\
\hline
\end{tabular}

\begin{tabular}{|c|c|c|c|c|c|c|c|c|c|c|c|c|c|c|c|c|c|c|c|c|c|c|c|c|c|c|c|c|c|c|c|c|c|c|c|}
\hline $\begin{array}{l}\text { Nucleotide } \\
\text { position }\end{array}$ & $\frac{\Omega}{6}$ & $\hat{\sigma}$ & Oే & $\begin{array}{l}\infty \\
\infty \\
\infty\end{array}$ & 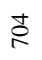 & 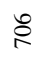 & 究 & જे & $\stackrel{\mathbb{N}}{\approx}$ & $\stackrel{2}{\gtrless}$ & $\stackrel{\infty}{\infty}$ & $\stackrel{2}{\curvearrowright}$ & $\bar{\infty}$ & $\frac{5}{\infty}$ & ఫ্ & 㐫 & $\tilde{\infty}$ & ஜே & $\approx$ & $\vec{\infty}$ & $\underset{\infty}{\hat{\infty}}$ & $\underset{\infty}{\infty}$ & $\stackrel{\infty}{\infty}$ & ষ্ণ & s̊ & $\frac{a}{a}$ & $\stackrel{心}{\Omega}$ & ๙ু & ลู & 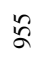 & నิ & ‡ా & ล̆ & ¿ & $\frac{1}{0}$ \\
\hline Consensus & $\mathrm{T}$ & $\mathrm{C}$ & $\mathrm{C}$ & A & $\mathrm{T}$ & A & $\mathrm{T}$ & G & G & G & G & G & G & A & A & $\mathrm{C}$ & $\mathrm{C}$ & $\mathrm{T}$ & C & G & A & $\mathrm{T}$ & $\mathrm{C}$ & A & $\mathrm{T}$ & $\mathrm{C}$ & $\mathrm{C}$ & $\mathrm{T}$ & $\mathrm{T}$ & $\mathrm{C}$ & A & $\mathrm{T}$ & G & $\mathrm{T}$ & $\mathrm{T}$ \\
\hline Vih7 & . & $\cdot$ & $\cdot$ & $\cdot$ & . & $\cdot$ & $\cdot$ & $\cdot$ & $\cdot$ & $\cdot$ & A & $\cdot$ & & ${ }^{\circ}$ & ${ }^{\circ}$ & 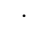 & $\mathrm{T}$ & . & & A & 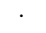 & 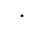 & & & & & & 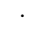 & . & & . & . & & . & $\mathrm{C}$ \\
\hline Ris50 & $\mathrm{C}$ & . & . & . & . & . & . & $\mathrm{A}$ & . & . & $\cdot$ & . & . & . & . & . & $\mathrm{T}$ & . & . & & G & . & . & . & . & . & . & . & . & . & . & . & & . & $\mathrm{C}$ \\
\hline Toi11 & $\cdot$ & $\mathrm{T}$ & . & . & . & . & $\cdot$ & $\cdot$ & . & . & A & . & . & . & . & . & $\cdot$ & . & $\mathrm{T}$ & . & $\cdot$ & . & . & . & . & . & $\mathrm{T}$ & . & . & . & . & . & . & . & $\mathrm{C}$ \\
\hline Ruu45 & . & $\cdot$ & . & . & . & $\cdot$ & . & . & . & A & $\cdot$ & . & . & . & . & . & . & . & $\cdot$ & . & . & . & . & $\mathrm{G}$ & . & . & $\cdot$ & . & . & $\mathrm{T}$ & . & . & . & . & $\mathrm{C}$ \\
\hline Sip62 & $\cdot$ & . & . & G & . & G & . & . & . & . & . & . & A & G & . & . & . & $\mathrm{C}$ & . & . & . & . & . & . & . & . & . & . & $\cdot$ & & . & . & & . & . \\
\hline DQ831831 & $\mathrm{C}$ & . & . & $\cdot$ & . & $\cdot$ & . & . & . & . & . & . & A & $\cdot$ & . & . & . & . & . & . & . & . & . & . & . & . & . & . & $\mathrm{C}$ & . & . & . & . & . & $\mathrm{C}$ \\
\hline Ris51 & $\cdot$ & . & . & . & . & . & . & . & . & . & . & $\cdot$ & $\cdot$ & . & . & $\mathrm{T}$ & . & $\cdot$ & . & . & $\cdot$ & . & . & . & $\mathrm{C}$ & $\cdot$ & . & . & $\cdot$ & . & . & . & . & . & . \\
\hline Ris54 & . & . & . & . & . & . & . & . & . & . & . & . & . & . & . & . & . & . & . & . & $\mathrm{C}$ & . & . & . & . & . & . & . & . & . & . & . & . & . & . \\
\hline Vii19 & . & . & $\mathrm{T}$ & . & . & . & . & . & . & . & . & . & . & . & . & . & . & . & . & . & . & . & $\cdot$ & . & . & . & . & . & . & . & . & . & & . & . \\
\hline Pir43 & . & . & $\cdot$ & . & . & . & . & . & . & . & . & . & . & . & . & . & . & . & . & . & . & . & $\mathrm{T}$ & . & . & . & . & . & . & . & . & . & . & . & . \\
\hline Vih2 & . & . & . & . & . & . & . & . & . & . & . & . & . & . & G & . & . & $\cdot$ & . & . & . & . & $\cdot$ & . & . & . & . & . & . & . & $\mathrm{G}$ & . & . & . & . \\
\hline Hel41 & . & . & . & . & . & . & . & . & . & . & . & . & . & . & G & . & . & . & . & . & . & . & . & . & . & . & . & . & . & . & & . & . & . & . \\
\hline Ris52 & . & . & . & . & . & . & . & . & A & . & . & A & . & . & G & . & . & . & . & . & . & . & . & . & . & . & . & . & . & . & . & . & . & . & . \\
\hline Ris56 & . & $\cdot$ & $\cdot$ & $\cdot$ & $\cdot$ & . & . & . & A & . & . & A & . & . & $\cdot$ & $\cdot$ & $\cdot$ & $\cdot$ & . & . & . & . & $\cdot$ & . & . & $\cdot$ & . & $\cdot$ & . & . & . & . & . & . & . \\
\hline Jam9 & . & . & . & . & . & . & . & . & $\cdot$ & . & . & $\cdot$ & . & . & G & . & . & . & . & . & . & . & $\mathrm{T}$ & . & . & $\mathrm{T}$ & . & $\mathrm{C}$ & . & . & . & . & . & . & . \\
\hline Ris60 & . & $\mathrm{T}$ & $\mathrm{T}$ & . & C & . & $\mathrm{C}$ & . & . & . & . & . & . & . & . & . & . & . & . & . & $\mathrm{G}$ & . & $\mathrm{T}$ & . & . & $\cdot$ & $\mathrm{T}$ & $\mathrm{C}$ & . & . & . & $\mathrm{C}$ & . & . & . \\
\hline Kuo12 & $\mathrm{C}$ & . & $\cdot$ & . & . & . & . & . & A & . & . & . & . & . & . & . & . & . & . & . & $\cdot$ & $\mathrm{C}$ & $\cdot$ & . & . & . & $\mathrm{T}$ & $\cdot$ & . & . & G & . & . & $\mathrm{C}$ & . \\
\hline Ris61 & $\mathrm{C}$ & . & $\cdot$ & $\cdot$ & $\cdot$ & $\cdot$ & $\cdot$ & $\cdot$ & $\cdot$ & $\cdot$ & $\cdot$ & $\cdot$ & $\cdot$ & $\cdot$ & $\cdot$ & . & $\cdot$ & $\cdot$ & $\mathrm{T}$ & $\cdot$ & $\cdot$ & . & . & . & . & $\cdot$ & $\mathrm{T}$ & $\cdot$ &. & . & $\cdot$ & $\cdot$ & $\mathrm{A}$ & . & . \\
\hline Amino acid & $\mathrm{N}$ & $\mathrm{L}$ & $\mathrm{P}$ & $\mathrm{Y}$ & $\mathrm{L}$ & $\mathrm{V}$ & I & $\mathrm{V}$ & $\mathrm{K}$ & $\mathrm{M}$ & $\mathrm{K}$ & $\mathrm{M}$ & $\mathrm{M}$ & $\mathrm{D}$ & $\mathrm{N}$ & $\mathrm{K}$ & $\mathrm{N}$ & $\mathrm{K}$ & $\mathrm{N}$ & $\mathrm{A}$ & $\mathrm{N}$ & $\mathrm{D}$ & $\mathrm{K}$ & I & $\mathrm{G}$ & I & $\mathrm{K}$ & $\mathrm{N}$ & I & $\mathrm{A}$ & $\mathrm{N}$ & $\mathrm{V}$ & $\mathrm{S}$ & $\mathrm{L}$ & I \\
\hline & $\cdot$ & $\cdot$ & $\cdot$ & $\cdot$ & $\cdot$ & $\cdot$ & $\cdot$ & $\cdot$ & $\cdot$ & $\cdot$ & $\cdot$ & $\cdot$ & $\cdot$ & $\cdot$ & $\cdot$ & $\cdot$ & $\cdot$ & $\cdot$ & $\cdot$ & $\cdot$ & $\cdot$ & $\cdot$ & $\cdot$ & . & . & . & $\cdot$ & $\cdot$ & . & $\cdot$ & $\cdot$ & $\mathrm{A}$ & . & $\cdot$ & $\cdot$ \\
\hline $\begin{array}{l}\text { Amino acid } \\
\text { position }\end{array}$ & 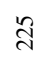 & ปั & $\stackrel{\infty}{\sim}$ & స్తి & $\ddot{n}$ & $\underset{\sim}{\text { సి }}$ & ฟี & $\sqrt{n}$ & $\stackrel{\infty}{\sim}$ & ฟิ & $\hat{\text { d }}$ & $\tilde{d}$ & $\vec{\nabla}$ & $\stackrel{m}{N}$ & $\vec{\sim}$ & $\stackrel{\infty}{\sim}$ & $\mathscr{\infty}$ & $\underset{\sim}{\infty}$ & 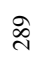 & $\overline{\grave{\lambda}}$ & ๙ิ & ৯े & $\underset{n}{\text { \& }}$ & ర్లి & है & s్ల & $\stackrel{\circ}{m}$ & $\frac{d}{m}$ & $\frac{\infty}{m}$ & $\frac{a}{m}$ & & $\stackrel{\infty}{N}$ & $m$ & $\tilde{m}$ & $\stackrel{\infty}{m}$ \\
\hline
\end{tabular}

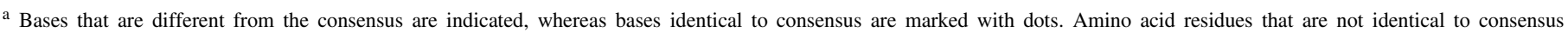
predictions owing to nucleotide substitution in some isolates are indicated at the bottom. Identical amino acids are marked with dots. 
apart from each other (Fig. 6). Ris61 was only 94 to $96 \%$ identical to all other isolates. Isolates Ris60 and Kuo12 were 95 to $97 \%$ identical to other isolates, which in turn were 97 to $99 \%$ identical to each other (Table 4).

The NP gene sequences of EMARAV were placed into two clusters according to neighbor-joining (Fig. 7) and maximum parsimony analyses (data not shown). Two isolates from Ristiina (Ris60 and Ris61) and one isolate from Kuopio (Kuo12) formed a cluster that was distinct from the other large cluster containing isolates from Finland, Russia, and Germany (Fig. 7). In the large cluster, isolates Ris52 and Ris56 from Ristiina were distinguished from other isolates.

Selection pressure on the NP gene. Results of ML analysis of selection pressures on sites (codons) yielded log likelihood values of $-1721.828,-1722.671,-1721.828,-1722.671,-1722.685$, and -1721.842 , under the models M0, M1a, M2a, M3, M7, and M8, respectively. The estimated $\omega$ value of 0.0123 was the same under all six different models, suggesting strong purifying selection on the encoded amino acids. Indeed, parameter estimates under the different models showed no codon to be under neutral or nearly neutral evolution (data not shown). The fact that the log likelihood under M3 (which assumes heterogeneous $\omega$ ratios among codons) was smaller than that under M0 (which assumes one $\omega$ ratio for all codons) further suggests homogeneous negative selective constraints on the encoded protein. Since the log likelihood values under models that assume positive selection (M2a and M8) were equal to the values under models assuming no positive selection (M1a and M7), respectively, results annulled the possibility that M1a versus M2a and M7 versus M8 likelihood ratio tests of positive selection would be significant.

\section{DISCUSSION}

The results of this study show that EMARAV is associated with the ringspot disease of mountain ash. The way in which the virus was named in the seminal study focused on molecular characterization (16) implicated that EMARAV could be commonly associated with the ringspot disease (EMARSD). This presumption was supported by a previous study, in which a pattern of three sizes of dsRNA $(2.3,1.5$, and $1.3 \mathrm{~kb})$ and in some cases also a fourth dsRNA of $7 \mathrm{~kb}$ was detected in leaves of only EMARSD-affected mountain ash trees in different parts of Germany (4). In the present study, new virus-specific detection tools such as RT-PCR and dot blot hybridization using digoxigenin-labeled probes allowed testing a large number of mountain ash trees for EMARAV. All trees exhibiting symptoms of EMARSD were virus-positive.

Expression of EMARSD symptoms showed no correlation with the variable relative concentrations of EMARAV RNA detected in leaves by dot blot hybridization. EMARAV was detected also in symptomless mountain ash trees whose leaves had higher concentrations of viral RNA than many leaves expressing the ringspot symptoms. In a previous study, yields of dsRNA obtained from EMARSD-affected leaves varied greatly but no dsRNA was detected in symptomless mountain ash leaves studied

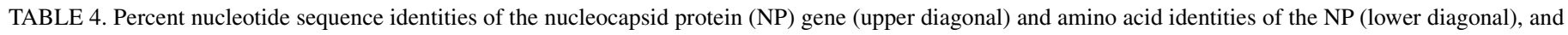
percent nucleotide sequence identities of the $3^{\prime}$ nontranslated region (3'UTR) among isolates of European mountain ash ringspot-associated virus

\begin{tabular}{|c|c|c|c|c|c|c|c|c|c|c|c|c|c|c|c|c|c|c|c|c|}
\hline & Isolate & Origin & 1 & 2 & 3 & 4 & 5 & 6 & 7 & 8 & 9 & 10 & 11 & 12 & 13 & 14 & 15 & 16 & 17 & 18 \\
\hline \multicolumn{21}{|c|}{ NP gene } \\
\hline 1 & Vih7 & Vihti & $* * *$ & 99 & 99 & 99 & 98 & 98 & 99 & 99 & 99 & 99 & 98 & 98 & 99 & 99 & 98 & 97 & 97 & 97 \\
\hline 2 & Ris50 & Ristiina & 100 & $* * *$ & 98 & 98 & 98 & 98 & 98 & 99 & 98 & 99 & 98 & 98 & 98 & 98 & 98 & 97 & 97 & 97 \\
\hline 3 & Toi11 & Toijala & 100 & 100 & $* * *$ & 98 & 98 & 98 & 98 & 98 & 98 & 98 & 98 & 98 & 98 & 98 & 98 & 97 & 97 & 97 \\
\hline 4 & Ruu45 & Ruukki & 100 & 100 & 100 & $* * *$ & 98 & 98 & 98 & 99 & 99 & 99 & 98 & 98 & 99 & 99 & 98 & 97 & 97 & 97 \\
\hline 5 & Sip62 & Sipoo & 100 & 100 & 100 & 100 & $* * *$ & 98 & 98 & 99 & 99 & 99 & 98 & 98 & 99 & 98 & 98 & 97 & 97 & 97 \\
\hline 6 & DQ831831 & Hamburg & 99 & 99 & 99 & 99 & 99 & $* * *$ & 98 & 98 & 98 & 98 & 98 & 98 & 98 & 98 & 98 & 97 & 97 & 97 \\
\hline 7 & Ris51 & Ristiina & 100 & 100 & 100 & 100 & 100 & 99 & $* * *$ & 99 & 99 & 99 & 98 & 98 & 99 & 99 & 99 & 97 & 97 & 97 \\
\hline 8 & Ris54 & Ristiina & 100 & 100 & 100 & 100 & 100 & 99 & 100 & $* * *$ & 99 & 99 & 99 & 99 & 99 & 99 & 99 & 98 & 98 & 97 \\
\hline 9 & Vih2 & Vihti & 100 & 100 & 100 & 100 & 100 & 99 & 100 & 100 & $* * *$ & 99 & 99 & 99 & 99 & 99 & 99 & 98 & 98 & 97 \\
\hline 10 & Hel41 & Helsinki & 100 & 100 & 100 & 100 & 100 & 99 & 100 & 100 & 100 & $* * *$ & 99 & 99 & 99 & 99 & 99 & 98 & 98 & 97 \\
\hline 11 & Ris52 & Ristiina & 99 & 99 & 99 & 99 & 99 & 99 & 99 & 99 & 99 & 99 & $* * *$ & 99 & 99 & 98 & 98 & 97 & 97 & 97 \\
\hline 12 & Ris56 & Ristiina & 99 & 99 & 99 & 99 & 99 & 99 & 99 & 99 & 99 & 99 & 100 & $* * *$ & 99 & 99 & 98 & 97 & 97 & 97 \\
\hline 13 & Pir43 & Pirkkala & 100 & 100 & 100 & 100 & 100 & 99 & 100 & 100 & 100 & 100 & 100 & 99 & $* * *$ & 99 & 99 & 98 & 98 & 98 \\
\hline 14 & Vii19 & Viipuri & 100 & 100 & 100 & 100 & 100 & 99 & 100 & 100 & 100 & 100 & 100 & 99 & 100 & $* * *$ & 99 & 97 & 97 & 97 \\
\hline 15 & Jam9 & Jämsä & 100 & 100 & 100 & 100 & 100 & 99 & 100 & 100 & 100 & 100 & 100 & 99 & 100 & 100 & $* * *$ & 97 & 97 & 98 \\
\hline 16 & Kuo12 & Kuopio & 100 & 100 & 100 & 100 & 100 & 99 & 100 & 100 & 100 & 100 & 100 & 99 & 100 & 100 & 100 & $* * *$ & 98 & 97 \\
\hline 17 & Ris61 & Ristiina & 100 & 100 & 100 & 100 & 100 & 99 & 100 & 100 & 100 & 100 & 100 & 99 & 100 & 100 & 100 & 100 & $* * *$ & 97 \\
\hline \multirow[t]{2}{*}{18} & Ris60 & Ristiina & 99 & 99 & 99 & 99 & 99 & 99 & 99 & 99 & 99 & 99 & 99 & 99 & 99 & 99 & 99 & 99 & 99 & $* * *$ \\
\hline & Isolate & Origin & 1 & 2 & 3 & 4 & 5 & 6 & 7 & 8 & 9 & 10 & 11 & 12 & 13 & 14 & 15 & 16 & 17 & 18 \\
\hline \multicolumn{21}{|c|}{ 3'UTR } \\
\hline 1 & Vih7 & Vihti & $* * *$ & 98 & 98 & 99 & 98 & 97 & 98 & 99 & 97 & 97 & 98 & 98 & 97 & 97 & 98 & 96 & 95 & 96 \\
\hline 2 & Ris50 & Ristiina & & $* * *$ & 98 & 98 & 97 & 97 & 98 & 98 & 97 & 96 & 97 & 97 & 97 & 96 & 97 & 95 & 94 & 95 \\
\hline 3 & Toi11 & Toijala & & & $* * *$ & 99 & 98 & 97 & 98 & 98 & 97 & 97 & 97 & 97 & 97 & 96 & 97 & 95 & 95 & 96 \\
\hline 4 & Ruu45 & Ruukki & & & & $* * *$ & 98 & 97 & 99 & 99 & 98 & 97 & 98 & 98 & 98 & 97 & 98 & 96 & 95 & 96 \\
\hline 5 & Sip62 & Sipoo & & & & & $* * *$ & 98 & 99 & 99 & 98 & 97 & 98 & 98 & 97 & 97 & 98 & 96 & 95 & 96 \\
\hline 6 & DQ831831 & Hamburg & & & & & & $* * *$ & 98 & 98 & 97 & 97 & 98 & 98 & 98 & 97 & 97 & 95 & 95 & 96 \\
\hline 7 & Ris51 & Ristiina & & & & & & & $* * *$ & 99 & 98 & 97 & 99 & 99 & 98 & 97 & 98 & 96 & 95 & 97 \\
\hline 8 & Ris54 & Ristiina & & & & & & & & $* * *$ & 98 & 98 & 99 & 99 & 98 & 97 & 99 & 97 & 96 & 97 \\
\hline 9 & Vih2 & Vihti & & & & & & & & & $* * *$ & 97 & 98 & 98 & 98 & 97 & 97 & 96 & 95 & 96 \\
\hline 10 & Hel41 & Helsinki & & & & & & & & & & $* * *$ & 97 & 97 & 97 & 96 & 97 & 95 & 94 & 95 \\
\hline 11 & Ris52 & Ristiina & & & & & & & & & & & $* * *$ & 99 & 98 & 97 & 98 & 96 & 95 & 96 \\
\hline 12 & Ris56 & Ristiina & & & & & & & & & & & & $* * *$ & 98 & 97 & 98 & 96 & 95 & 96 \\
\hline 13 & Pir43 & Pirkkala & & & & & & & & & & & & & $* * *$ & 99 & 97 & 96 & 95 & 96 \\
\hline 14 & Vii19 & Viipuri & & & & & & & & & & & & & & $* * *$ & 97 & 95 & 94 & 95 \\
\hline 15 & Jam9 & Jämsä & & & & & & & & & & & & & & & $* * *$ & 96 & 95 & 97 \\
\hline 16 & Kuo12 & Kuopio & & & & & & & & & & & & & & & & $* * *$ & 96 & 97 \\
\hline 17 & Ris61 & Ristiina & & & & & & & & & & & & & & & & & $* * *$ & 97 \\
\hline 18 & Ris60 & Ristiina & & & & & & & & & & & & & & & & & & $* * *$ \\
\hline
\end{tabular}


in Germany (4). The possibility cannot be excluded that some leaves at the top of the tree out of reach display symptoms and remain unnoticed. However, a few smaller infected trees could be examined for every leaf several times over the summer in our studyand lack of symptoms was ascertained (e.g., sample E5 in Fig. 5). These results showed that mountain ash can carry a latent infection of EMARAV.

Symptom expression in virus-infected plants is a function of virus-host interactions and environment (15). It is possible that latent infections of mountain ash with EMARAV are more common in Finland than Germany because the populations of mountain ash in Finland are genetically differentiated from the populations in central and southern Europe (22). Mountain ash trees in Finland seem to tolerate EMARSD well although detailed studies on putative negative effects on the survival and overwintering of seedlings and larger trees are lacking. EMARSD is the only major disease affecting mountain ash in Finland, which suggests that infection with EMARAV does not greatly increase the propensity of trees to other diseases. Symptom development in EMARAV-infected mountain ash leaves might also be affected by light and/or temperature. For example, in the experiments of this study, infected leaves developed no symptoms in a growth room under low light intensity and high temperature, whereas the young 1-week-old leaves of the same tree developed typical ringspot symptoms outdoors. Ringspots on leaves were visible until senescence and no signs of recovery were observed.

Observation of the same mountain ash trees in 2007 and 2008, and some of them also in the previous years, indicated that the trees which displayed symptoms continued doing so year after year. However, there were large variations in the extent to which

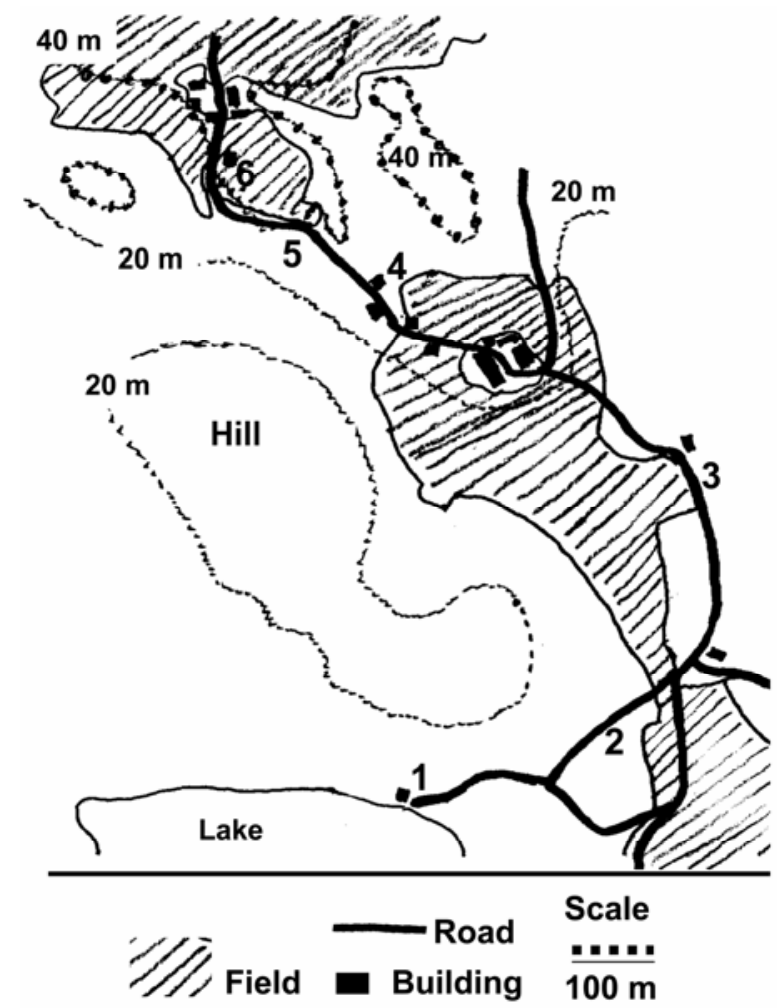

Fig. 6. Spatial distribution of mountain ash trees (numbers 1 to 6) sampled for detection of European mountain ash ringspot-associated virus (EMARAV) at one site in Ristiina, Finland. The landscape was hilly, which is indicated by two types of dotted lines marking the altitude of 20 and $40 \mathrm{~m}$ from the level of the lake. The area was covered by pine forest including birch in moist dells. Arable field areas (marked) provided the only open landscape. All trees except no. 1 grew close to the edge of a field. Distances between the trees nos. 1 to 6 were as follows: from 1 to 2, $200 \mathrm{~m} ; 2$ to 3, $200 \mathrm{~m} ; 3$ to 4, $400 \mathrm{~m} ; 4$ to 5, $100 \mathrm{~m}$; and 5 to $6,100 \mathrm{~m}$. The isolates of EMARAV characterized from the trees were as follows: 1, Ris51; 2, Ris52; 3, Ris54; 4, Ris56; 5, Ris61; and 6, Ris60. the leaflets of a leaf, leaves of a branch, and different branches of the tree displayed symptoms in different years (our unpublished data). Furthermore, the same tree could display many types of symptoms (Fig. 2). It was hypothesized that EMARAV may be transported from the smaller branches to the main branches, trunk or roots in the autumn, or degraded in smaller branches. In the spring, transportation of EMARAV from the putative virus reservoirs of the tree to the small branches and leaves might then determine the rate of symptom development. However, the data obtained did not support this theory. The apical parts of branches contained infectious EMARAV in the last winter months when the tree was still dormant. Samples were taken from the northern side of the tree under shade of pine trees, so to be sure that buds were not activated by direct sunshine. These results excluded one explanation to the mechanism behind seasonal variation of symptoms but the matter requires further study.

EMARAV showed little genetic variability based on the RNA3 sequences of 16 isolates from Finland, one isolate from a nearby district in Russia, and the previously characterized isolate from Germany. Selection pressures directed to the NP gene were analyzed in an attempt to find indications of evolutionary constraints met by EMARAV. The selective constraints on the nucleocapsid protein $(\mathrm{N})$ gene and four other genes of TSWV are similar and purifying selection seems to act to preserve protein functions (28). Similarly, the NP of EMARAV was found to be under strong negative selection. The limited variability of NP gene sequences among isolates of EMARAV resulted in amino acid substitutions at two positions in the $\mathrm{N}$ terminus and one position in the $\mathrm{C}$ terminus of NP in four isolates, but no statistical support was obtained for positive selection at these sites. In contrast, similar analysis of the $\mathrm{N}$ gene of TSWV has shown that certain codons are under positive selection (28). A major difference between TSWV and EMARAV is that TSWV has the largest number of known host species among the plant viruses described (at least 925 species in 70 families) (8), whereas the only known host for EMARAV is mountain ash. Infection of many unrelated host species by TSWV should cause a heavy selection pressure on the virus but, surprisingly, selective constraints appear to be only modest (28). It is worth revisiting the selective pressures on the genome of EMARAV when additional isolates have been characterized from central Europe and can be included for comparison. Knowledge on variability of biological properties among isolates

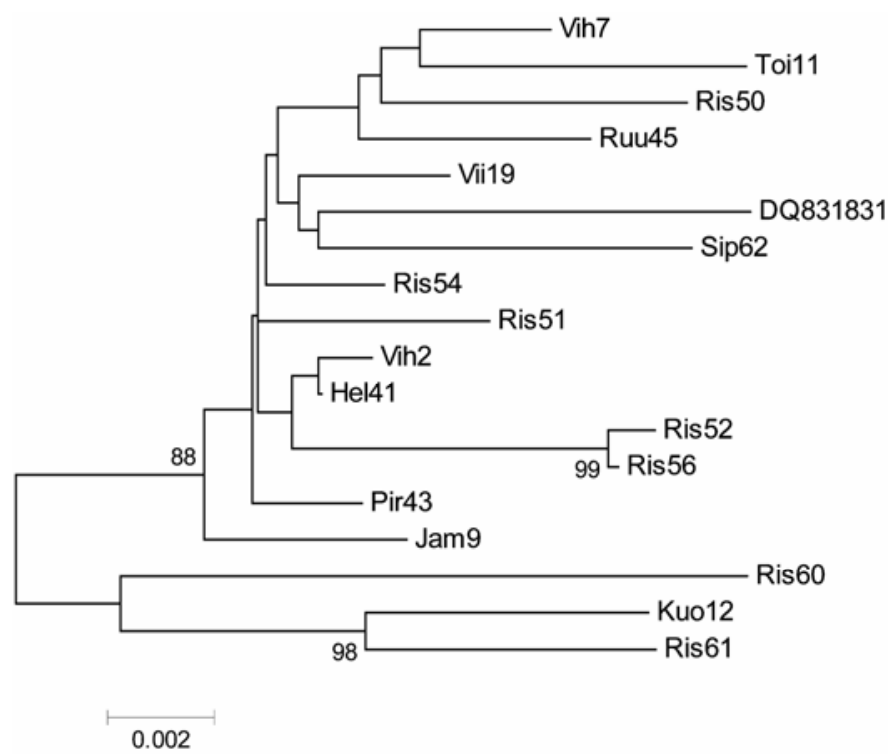

Fig. 7. Phylogenetic analysis of the nucleocapsid protein gene sequences of European mountain ash ringspot-associated virus isolates. Only bootstrap values greater than 80 are shown. The bar indicates a genetic distance as Kimura units (13). 
of EMARAV would also be valuable but will be very challenging to study because no success has been met with transmission of EMARAV to herbaceous hosts and the vector of the virus is unknown.

A local population represented by six isolates of EMARAV at one site in Ristiina (Fig. 6) exhibited as wide a genetic variability as the 12 isolates from distant locations several hundreds to thousand kilometers apart. Phylogenetic analysis of the NP gene sequences placed isolates of EMARAV to three statistically supported clusters, each containing isolates from the same subpopulation in Ristiina. Isolates Ris60 and Ris61 were sampled from trees $100 \mathrm{~m}$ apart from the edges of the same field. They belonged to a cluster that also included isolate Kuo12 from Kuopio, $200 \mathrm{~km}$ from Ristiina. On the other hand, isolate Ris56 sampled from a tree $100 \mathrm{~m}$ from Ris61 belonged to another cluster and was closest related to isolate Ris52 obtained from the other side of the same field. Ris52 and Ris56 were unique compared with any other isolate. The remaining two isolates Ris51 and Ris54 were closely related to isolates from distant locations in Finland and the isolates from Russia and Germany. The trees infected with Ris51 and Ris54 were $200 \mathrm{~m}$ from the tree infected with Ris52 but in opposite directions from this tree. These results revealed no geographical differentiation among populations of EMARAV, whereas a metapopulation model has been proposed for TSWV. Isolates of TSWV and another tentative tospovirus, Irish yellow spot virus (IYSV), are clustered according to the geographical origin based on phylogenetic analysis of the $\mathrm{N}$ gene sequences, which may be attributed to founder effects $(19,28)$. However, there are also isolates of TSWV and IYSV from different continents and hosts that are placed to the same cluster in phylogenetic analysis of the respective virus $(19,28)$. The results on EMARAV resemble those previously reported on TSWV and IYSV in terms of lack of nucleotide variation and low haplotype diversity within the subpopulation studied $(19,28)$. Analysis of many isolates from additional subpopulations would be needed to test the metapopulation model on EMARAV.

The ecological significance of EMARAV to mountain ash is not known but seems worthwhile to study. Mountain ash is one of the most common deciduous tree species in the forests of Finland and many if not most trees display the symptoms of EMARSD. It is a major disease of mountain ash in northern and central Europe $(7,11,12,20)$. Results of this study showed that EMARAV also causes symptomless infections and is therefore even more common in the wild mountain ash trees in Finland than previously thought. It is a new tentative example of the Bunyaviridae members that occur in the wild in northern Europe. The previous examples infect animals, e.g., the widely studied Puumala virus (genus Hantavirus) that infects rodents (1) and Uukuniemi virus (genus Phelobovirus) that infects ticks $(8,23,29)$. The virus-specific detection tools for EMARAV described here and in another recent study (17) should be useful for similar studies in other countries and also for detection of other possible hosts of EMARAV.

\section{ACKNOWLEDGMENTS}

We thank the laboratories of H.-P. Mühlbach and C. Büttner for the interesting discussions and mutual exchange of unpublished data.

\section{LITERATURE CITED}

1. Asikainen, K., Hänninen, T., Henttonen, H., Niemenmaa, J., Laakkonen, J., Andersen, H. K., Leirs, H., Vaheri, A., and Plyusnin, A. 2000. Molecular evolution of Puumala hantavirus in Fennoscandia: Phylogenetic analysis of strains from two recolonization routes, Karelia and Denmark. J. Gen. Virol. 81:2833-2841.

2. Balhoff, J. P., and Wray, G. A. 2005. Evolutionary analysis of the well characterized endo16 promoter reveals substantial variation within functional sites. Proc. Natl. Acad. Sci. USA 102:8591-8596.

3. Baur, E. 1907. Über infektiöse Chlorosen bei Ligustrum, Laburnum, Fraxinus, Sorbus und Ptelea. Ber. Dt. Bot. Ges. 25:410-413.
4. Benthack, W., Mielke, N., Büttner, C., and Mühlbach, H. P. 2005. Doublestranded RNA pattern and partial sequence data indicate plant virus infection associated with the ringspot disease of European mountain ash (Sorbus aucuparia L.). Arch. Virol. 150:37-52.

5. Boom, R., Sol, C. J. A., Salimans, M. M. M., Jansen, C. L., Wertheim-van Dillen, P. M. E., and van der Noordaa, J. 1990. Rapid and simple method for purification of nucleic acids. J. Clin. Microbiol. 28:495-503.

6. Cooper, J. I. 1979. Virus Diseases of Trees and Shrubs. Institute of Terrestial Ecology, Oxford, UK.

7. Ebrahim-Nesbat, F., and Izalpanah, K. 1992. Virus-like particles associated with ringfleck mosaic of mountain ash and mosaic disease of raspberry in the Bavarian forest. Eur. J. Forest Pathol. 22:1-10.

8. Fauquet, C. M., Mayo, M. A., Maniloff, J., Desselberger, U., and Ball, L. A. (eds.) 2005. Virus Taxonomy: Eighth Report of the International Committee on Taxonomy of Viruses. Elsevier Academic Press, San Diego, CA.

9. Fulton, R. W. 1972. Apple mosaic virus. No. 83 in: CMI/AAB Descriptions of Plant Viruses. Commonwealth Mycological Institute/Association of Applied Biologists, Kew, UK.

10. Goldman, N., and Yang, Z. 1994. A codon-based model of nucleotide substitution for protein coding DNA sequences. Mol. Biol. Evol. 11:725-736.

11. Jamalainen, E. A. 1957. On plant virus diseases and viruslike diseases in Finland. Publications of the Finnish State Agricultural Research Board No. 158. Agricultural Research Centre, Tikkurila, Finland.

12. Kegler, H. 1959/60. Das Ringfleckmosaik der Eberesche. Phytopathol. Z. 37:214-216.

13. Kimura, M. 1980. A single method for estimating evolutionary rates of base substitutions through comparative studies of nucleotide sequences. J. Mol. Evol. 16:111-120.

14. Lister, R. M. 1970. Apple chlorotic leaf spot virus. No. 30 in: CMI/AAB Descriptions of Plant Viruses. Commonwealth Mycological Institute/ Association of Applied Biologists, Kew, UK.

15. Matthews, R. E. F. 1991. Factors influencing the course of infection and disease. Pages 450-469 in: Plant Virology. 3rd ed. Academic Press, San Diego, CA.

16. Mielke, N., and Muehlbach, H.-P. 2007. A novel, multipartite, negativestrand RNA virus is associated with ringspot disease of European mountain ash (Sorbus aucuparia L.). J. Gen. Virol. 88:1337-1346.

17. Mielke, N., Weber, M., Khan, S., and Muehlbach, H.-P. 2008. Detection of European mountain ash ringspot-associated virus (EMARAV) in Sorbus aucuparia $\mathrm{L}$. by specific antiserum and reverse transcription-PCR. Forest Pathol. 38:371-380.

18. Miyata, T., Miyazawa, S., and Yasunaga, T. 1979. Two types of amino acid substitutions in protein evolution. J. Mol. Evol. 12:219-236.

19. Pappu, H. R., duToit, L. J., Schwartz, H. F., and Mohan, S. K. 2006. Sequence diversity of the nucleoprotein gene of iris yellow spot virus (genus Tospovirus, family Bunyaviridae) isolates from the western region of the United States. Arch. Virol. 151:1015-1023.

20. Polak, Z., and Zieglerova, J. 1996. Towards ringspot and variegation in mountain ash leaves. J. Plant Dis. Prot. 103:432-435.

21. Raspé, O., Findlay, C., and Jacquemart, A. L. 2000. Sorbus aucuparia L. J. Ecol. 88:910-930.

22. Raspé, O., and Jacquemart, A. L. 1998. Allozyme diversity and genetic structure of European populations of Sorbus aucuparia L. (Rosaceae: Maloideae). Heredity 81:537-545.

23. Saikku, P., and Brummer-Korvenkontio, M. 1975. Tick-borne viruses in Finland. Med. Biol. 53:317-320.

24. Saitou, N., and Nei, M. 1987. The neighbor-joining method, a new method for reconstructing phylogenetic trees. Mol. Biol. Evol. 4:406-425.

25. Sweet, J. B., and Campbell, A. I. 1976. Pome fruit virus infections of some woody ornamental and indigenous species of Rosaceae. J. Hort. Sci. 51:91-97.

26. Tamura, K., Dudley, J., Nei, M., and Kumar, S. 2007. MEGA4: Molecular evolutionary genetics analysis (MEGA) software version 4.0. Mol. Biol. Evol 24:1596-1599.

27. Thompson, J. D., Higgins, D. G., and Gibson, T. J. 1994. CLUSTAL W: Improving the sensitivity of progressive multiple sequence alignment through sequence weighting, position-specific gap penalties and weight matrix choice. Nucleic Acids Res. 22:4673-4680.

28. Tsompana, M., Abad, J., Purugganan, M., and Moyer, J. W. 2005. The molecular population genetics of the Tomato spotted wilt virus (TSWV) genome. Mol. Ecol. 14:53-66.

29. von Bonsdorff, C. H., Saikku, P., and Oker-Blom, N. 1969. The inner structure of Uukuniemi virus and two Bunyamwera Supergroup arboviruses. Virology 39:342-344.

30. Wong, W. S. W., Yang, Z., Goldman, N., and Nielsen, R. 2004. Accuracy and power of statistical methods for detecting adaptive evolution in protein coding sequences and for identifying positively selected sites. Genetics 168:1041-1051.

31. Yang, Z. 2007. PAML 4: A program package for phylogenetic analysis by maximum likelihood. Mol. Biol. Evol. 24:1586-1591. 